\title{
A solitary intramedullary neurofibroma in the cervicothoracic spinal cord: a case study and literature analysis
}

\author{
Zhengkai Zhao ${ }^{1}$, Jianlin $\mathrm{Li}^{1}$, Yuanyuan $\mathrm{Chen}^{2}$, Jian Liu ${ }^{1}$, Qiuyi Cai ${ }^{1}$, Yi Li ${ }^{1}$, Jiayu Zou ${ }^{1}$, Jianshou Zhou ${ }^{1}$, \\ Ya Li ${ }^{1}$, Yong Liang ${ }^{1}$, Hao Yang $^{1} \wedge$ \\ ${ }^{1}$ Department of Radiology, The Third People's Hospital of Chengdu, Chengdu, China; ${ }^{2}$ Department of Pathology, The Third People's Hospital of \\ Chengdu, Chengdu, China \\ Correspondence to: Hao Yang. Department of Radiology, The Third People's Hospital of Chengdu, 82 Qinglong Street, Chengdu 610031, China. \\ Email: yhfyj129@163.com.
}

Submitted Sep 26, 2021. Accepted for publication Jan 04, 2022.

doi: 10.21037/qims-21-940

View this article at: https://dx.doi.org/10.21037/qims-21-940

\section{Introduction}

Spinal neurofibromas are typically located in the extramedullary subdural area. However, it is rare that this tumor is found in the spinal cord. Theincidence of intramedullary neurofibroma is much lower than that of schwannoma, ependymoma, or glioma. Spinal intramedullary neurofibroma is now recognized as a rare entity in which the predominant cell type is the perineurial cell. This is different from the more common spinal schwannoma (1). The eighth and ninth reported cases of solitary intramedullary neurofibroma were reported in 2017 by Poriazova et al. and Rosario et al., respectively $(2,3)$. We now present a rare, and only the tenth, case of solitary intramedullary neurofibroma at the C7-T2 levels, in which fat tissue was found in the posterior aspect of the lesion, with no neurofibromatosis.

\section{Case presentation}

All procedures performed in this study were in accordance with the ethical standards of the institutional and/or national research committee(s) and with the Helsinki Declaration (as revised in 2013). Written informed consent was obtained from the patient for publication of this case report and accompanying images. A copy of the written consent form is available for review by the editorial office of this journal.

A 43-year-old man presented with back pain and bilateral shoulder pain with no obvious cause. The pain was aggravated in the supine position, which affected sleep and caused numbness in both upper limbs. The physical examination revealed stiffness of the neck muscles and pain after applying compression on the $\mathrm{C} 7-\mathrm{T} 2$ vertebrae. Magnetic resonance imaging (MRI) revealed a clearly defined intramedullary mass in the spinal cord at the C7-T2 levels measuring approximately $1.5 \mathrm{~cm} \times 1.1 \mathrm{~cm} \times 3.3 \mathrm{~cm}$. The T1-weighted and T2-weighted images of the lesion both showed hyperintense and hypointense mixed signals (Figure $1 A, 1 B$ ). After gadolinium injection, the intramedullary lesion was inhomogeneously enhanced (Figure 1C). Onthe T1-weighted and T2-weighted images, a patch of a hyperintense signal was observed in the posterior part of the lesion.

The patient underwent surgery. We performed laminectomy at the C7-T2 levels to expose the lesion. After opening the dura, the spinal cord was swollen, and the nerveroots were surrounded and adhered to by fatty tissue. After performing myelotomy, a hard white tumor could be seen below the fatty tissue and was confirmed as intramedullary (Figure 2). The spinal cord and nerve roots were pushed by the tumor, which was not clearly demarcated from the nerve tissue. Transcranial electrical stimulation of motor-evoked potentials and multipoint

^ ORCID: Zhengkai Zhao, 0000-0002-3138-6896; Hao Yang, 0000-0003-3121-1612. 

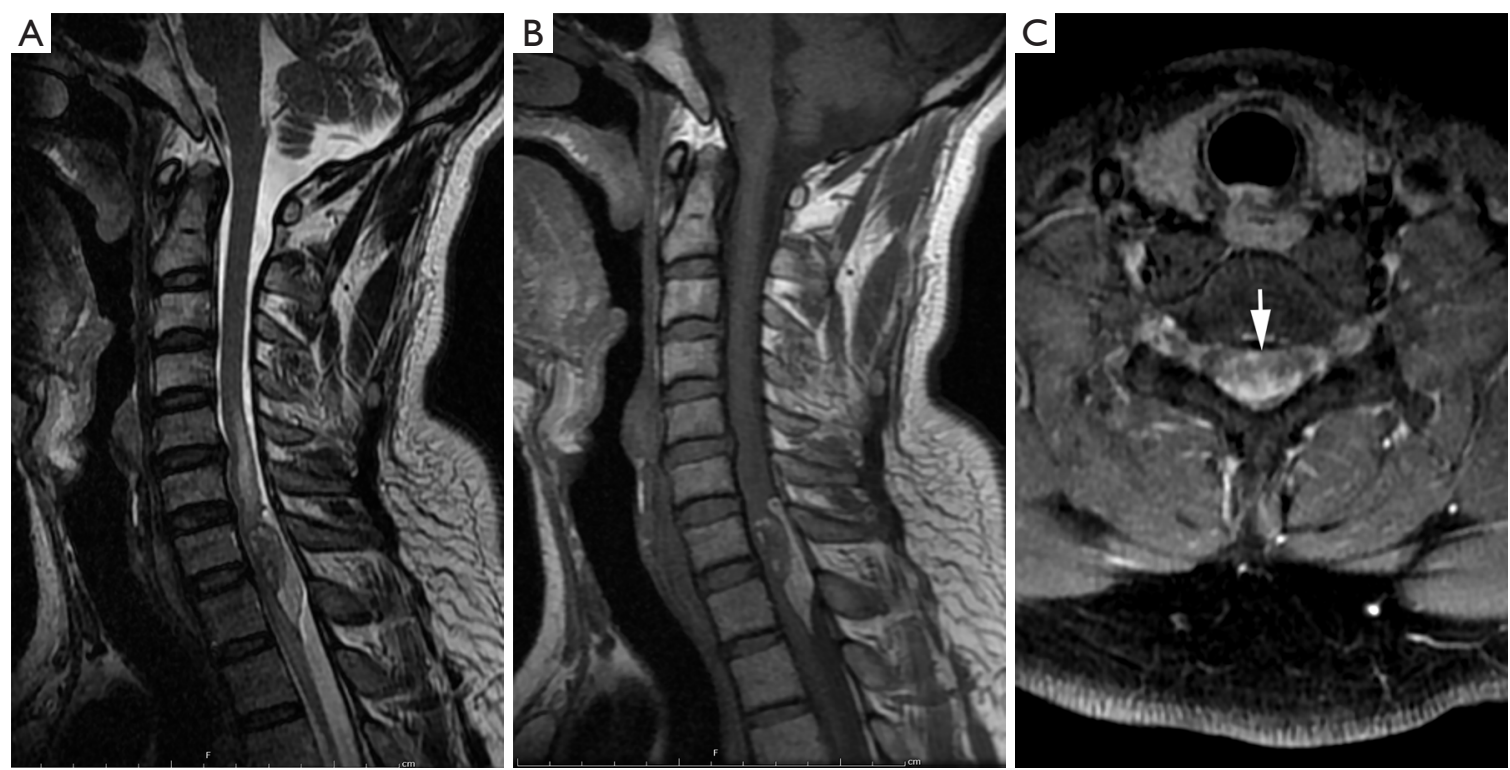

Figure 1 MRI findings of the lesion. Sagittal (A) T2-weighted images and sagittal (B) T1-weighted images of the lesion show mixed hyperintense and hypointense signals. After gadolinium injection; axial (C) inhomogeneous enhancement of the intramedullary lesion was observed (white arrow). MRI, magnetic resonance imaging.

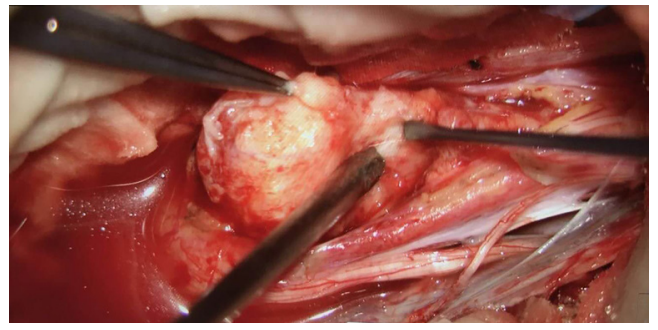

Figure 2 Photograph showing the hard white tumor after myelotomy.

recorded somatosensory evoked potentials were used in spinal cord surgery. We expanded the resection area along the boundary of the lesion, separated the tumor from the nerve root and from the spinal cord, and performed total resection of the tumor.

The histopathological examination showed that the tumor was a fusiform mass without a thick envelope, containing fat and a small amount of nerve tissue. The tumor cells were mainly long spindle-shaped cells arranged in waves and dispersed in the mucus matrix (Figure 3A). The cytoplasm of the tumor cells was slightly stained with hematoxylin-eosin. The nucleus was diamond shaped, slender, and curved with slightly dark staining. Collagen fibers were seen in the stroma.
Immunohistochemical staining revealed partial positive staining of tumor cells for the S-100 protein (Figure 3B) and CD34 (Figure 3C). Most of the tumor cells showed negative staining for epithelial membrane antigen (EMA). Only a limited number of cells showed positive staining, and these cells were believed to be those in the residual perineurium (Figure 3D). SOX10 staining of the tumor cells was positive. For the tumor cells that were examined, staining for glial fibrillary acidic protein (GFAP), calretinin, and CD56 was negative. The Ki-67 labeling index of the tumor cells was less than 3\%. Primarily based on the S-100 protein, CD34, and EMA findings, the intramedullary tumor was diagnosed as neurofibroma.

At the 1-month postoperative follow-up, the patient had paresthesia below the T6 plane and displayed grade 4 muscle strength in both lower limbs. At the 1-year followup, the muscle strength in the patient's right lower limb had recovered, while the left lower limb was still testing at a grade 4 level. Postoperative MRI did not reveal any residual tumor. In addition, the subarachnoid space was widened, and the spinal cord had become thinner at the C7-T1 levels (Figure $4 A, 4 B)$. Table 1 shows the timeline of important events.

\section{Discussion}

Intramedullary neurofibromas are particularly rare because 

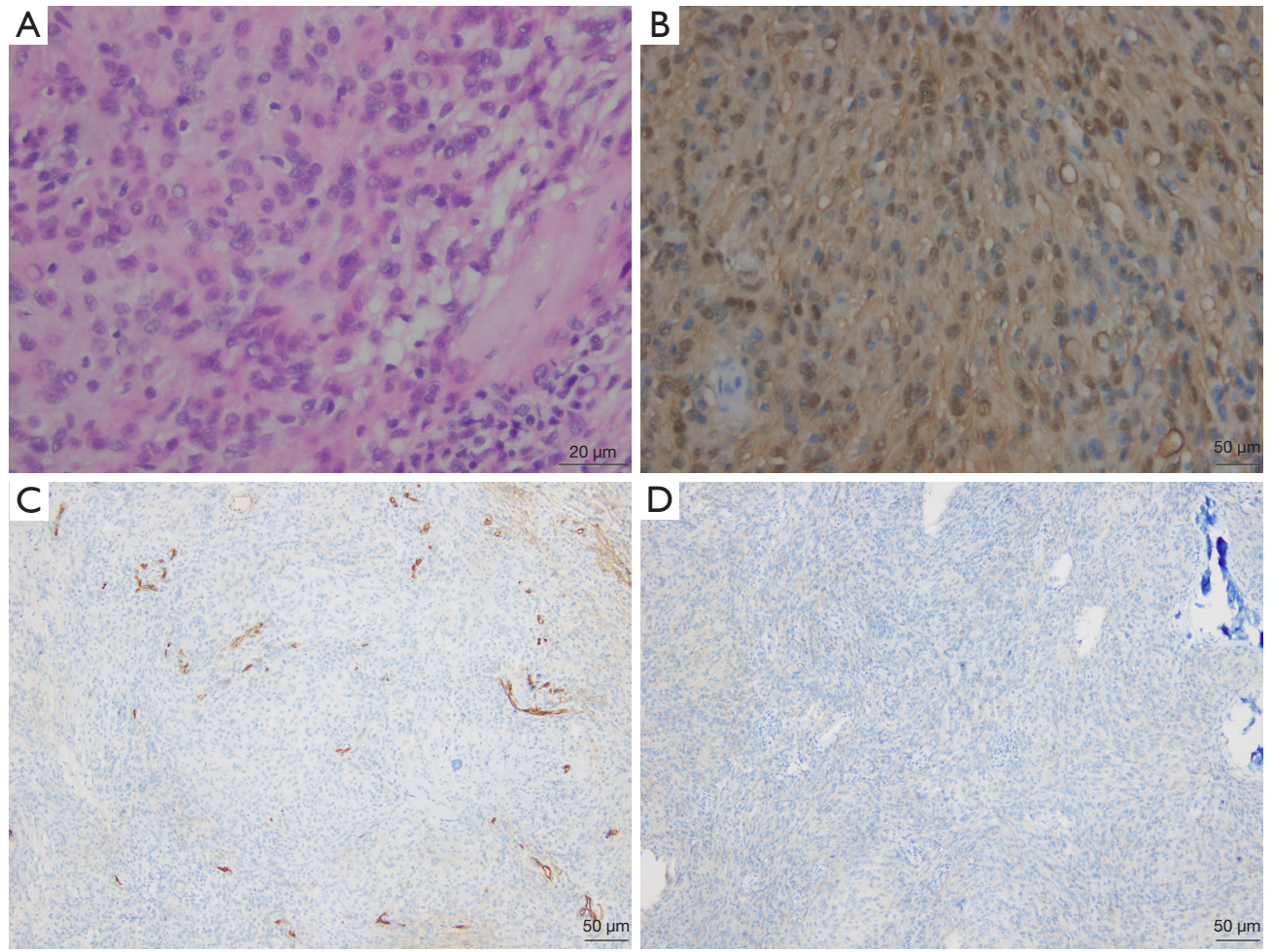

Figure 3 Histological findings of the intramedullary neurofibroma. (A) Photomicrograph showing spindle cells dispersed in the mucus matrix (HE stain, magnification $\times 400$ ); (B) immunohistochemical staining showing positive staining of tumor cells for the S-100 protein (magnification $\times 400$ ); (C) immunohistochemical staining showing partial positivity of tumor cells for CD34 (magnification $\times 100$ ); (D) EMA staining showing that most of the tumor cells were negative for EMA, while only a limited number of cells were positive for EMA, and these cells were believed to be those in the residual perineurium (magnification $\times 100$ ). HE, hematoxylin and eosin; EMA, epithelial membrane antigen.
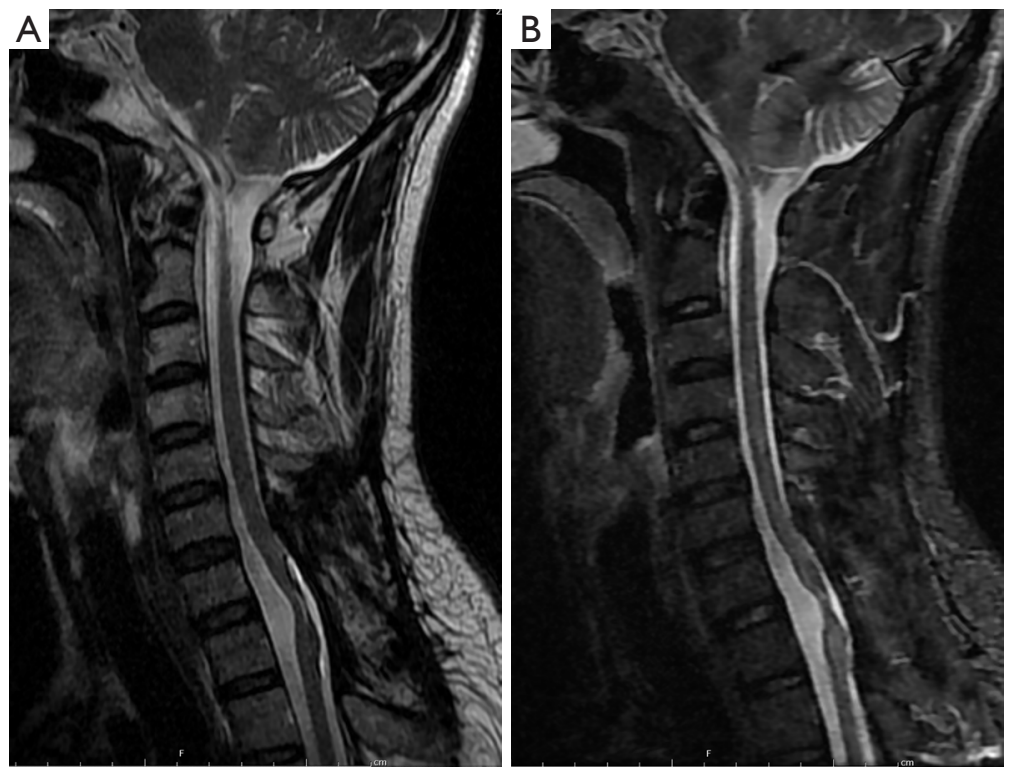

Figure 4 MRI after spinal cord surgery. Sagittal (A) T2-weighted images and sagittal (B) short inversion time inversion recovery images show that the subarachnoid space has widened, and the spinal cord has become thinner at the C7-T1 levels. MRI, magnetic resonance imaging. 
Table 1 Timeline of important events

\begin{tabular}{l}
\hline Time $\quad$ Event \\
\hline June $19^{\text {th }}, 2019$ Back pain and bilateral shoulder pain \\
June $22^{\text {th }}, 2019$ Enhanced MRI confirmed intramedullary lesions \\
June $26^{\text {th }}, 2019$ Surgical resection of intramedullary lesions \\
July $10^{\text {th }}, 2019$ Combined with histopathology and immunohistochemistry, the tumor was diagnosed as intramedullary neurofibroma. \\
July $12^{\text {th }}, 2019$ Discharged \\
July $29^{\text {th }}, 2019$ Follow-up; paresthesia below the T6 plane and grade 4 muscle strength in both lower limbs. \\
June $08^{\text {th }}, 2020$ Follow-up; muscle strength in the patient's right lower limb had recovered, while that in the left lower limb was still grade 4
\end{tabular}

$\mathrm{MRI}$, magnetic resonance imaging.

there are usually no Schwann cells in the spinal cord under normal circumstances. In the case report published by Tonnis et al. (4), only 1 out of the 82 spinal neurofibroma cases was located inside the spinal cord. Among the 78 cases, Nittner (5) also found an intramedullary spinal neurofibroma within one of the cases. A literature review was conducted through the PubMed database, uncovering that only 9 cases of intramedullary neurofibromas have been published to date (Table 2) (2,3,6-12). The present case may be the 10th recorded case of intramedullary neurofibromas. The main clinical manifestations of intramedullary neurofibroma are motor, sensory, and sphincter dysfunction, while nerve root pain is not a common feature. Intramedullary neurofibromas are mainly located in the cervical spinal cord $(70 \%)$, followed by the thoracic region (20\%) and the cauda equina (10\%) (2-12).

MRI is the preferred method to diagnose intramedullary tumors, as it offers precise anatomical delineation of the lesions and is helpful for the development of surgical plans. Neurofibroma showed a hypointense signal on T1WI. On T2WI and enhanced T1WI, the target sign was observed, seen as a hypointense signal in the centermost area of the lesion. Whereas on the periphery of the tumor, a hyperintense signal was found. The hypointense signal could be caused by the collagen fiber tissue in the centermost area, while the peripheral hyperintense signal could be explained by the annular mucus matrix. Intramedullary neurofibromas usually exhibit clear boundaries on contrastenhanced MRI. Some intramedullary neurofibromas are slightly enhanced, while others are significantly enhanced. The tumor often grows on the dorsolateral side of the spinal cord, which is helpful in differentiating it from other intramedullary tumors. However, distinguishing intramedullary neurofibromas from other common spinal cord tumors such as ependymomas and astrocytomas is typically challenging, and the final diagnosis often depends on pathological findings. Ependymomas usually occur in the lower lumbar spinal cord, conus medullaris, or cauda equina. Most of these are benign, with expansive growth and clear boundaries. Ependymoma has a high rate of cystic transformation, and most of the solid parts are uniformly enhanced. Astrocytoma usually occurs in the cervical and thoracic segments. Most astrocytomas show invasive growth with unclear borders. Cystic degeneration can occur in tumors or, even worse, lead to syringomyelia. Most, if not all, the solid parts in the astrocytoma are not obviously enhanced. In our patient, the intramedullary neurofibroma was located on the dorsolateral side of the spinal cord. In addition, this is the first reported case in which fat tissue was found at the posterior part of the lesion. In addition, the lesion was evaluated by enhanced MRI.

Neurofibromas contain a variety of cells, including Schwann cells, nerve fascicular-like cells and fibroblasts $(13,14)$. Schwannomas should have a capsule. Under microscopic observation, an alternating distribution of the fascicular area and of the reticular area is discovered. Alongside these observations, a verocay body and perivascular hyaline degeneration could also be observed in schwannoma. However, in this case, the capsule and the typical morphological area could not be found. Immunohistochemical staining for the S-100 protein and CD34 has been used as a diagnostic marker for different eating neurofibromas from schwannomas $(13,14)$. CD34 isa marker used to detect hematopoietic progenitor cells and nerve sheath cells $(15,16)$. Usually, schwannomas exhibit higher immunoreactivity results for the S-100 protein and CD34. In our patient, the tumor cells stained positive for CD34 and the S-100 protein. The perineuronal cells were 
Table 2 Summary of previously reported cases of intramedullary neurofibroma

\begin{tabular}{|c|c|c|c|c|c|c|c|c|c|}
\hline $\begin{array}{l}\text { Case, } \\
\text { no. }\end{array}$ & Author (year) & Age/sex & Symptoms & Location & $\begin{array}{l}\text { Radiological } \\
\text { examination }\end{array}$ & $\begin{array}{l}\text { NF1 or } \\
\text { NF2 }\end{array}$ & $\begin{array}{l}\text { Surgical } \\
\text { resection }\end{array}$ & $\begin{array}{l}\text { Pathological } \\
\text { examination }\end{array}$ & Follow-up \\
\hline 1 & $\begin{array}{l}\text { Gelabert et al., } \\
1996(6)\end{array}$ & $50 / F$ & Tetraparesis & C2-4 & MRI & None & $\begin{array}{l}\text { Complete } \\
\text { excision }\end{array}$ & $\mathrm{HE}$ & Recovery \\
\hline 2 & $\begin{array}{l}\text { Oka et al., } \\
1992(7)\end{array}$ & $62 / F$ & $\begin{array}{l}\text { Paresthesia of hands } \\
\text { and feet }\end{array}$ & C3-4 & $\mathrm{CT}, \mathrm{MRI}$ & None & $\begin{array}{l}\text { Complete } \\
\text { excision }\end{array}$ & HE, Bodian & Recovery \\
\hline 4 & $\begin{array}{l}\text { Gelabert González } \\
\text { et al., } 1985 \text { (9) }\end{array}$ & $29 / F$ & Paresthesia of hands & C2-4 & $\begin{array}{l}\mathrm{CT}, \\
\text { myelogram }\end{array}$ & None & $\begin{array}{l}\text { Complete } \\
\text { excision }\end{array}$ & $\mathrm{HE}$ & Recovery \\
\hline 5 & $\begin{array}{l}\text { Sharma et al., } \\
1984(10)\end{array}$ & $27 / M$ & $\begin{array}{l}\text { Weakness in the upper } \\
\text { and lower limbs }\end{array}$ & C5-6 & Myelogram & None & $\begin{array}{l}\text { Near } \\
\text { totalexcision }\end{array}$ & $\mathrm{HE}$ & $\begin{array}{l}\text { Strength of the } \\
\text { lower limbs had } \\
\text { recovered to grade } \\
\text { III }\end{array}$ \\
\hline 7 & $\begin{array}{l}\text { Arishima et al., } \\
2014(12)\end{array}$ & $52 / \mathrm{M}$ & $\begin{array}{l}\text { Paraparesis, bladder, } \\
\text { and rectal disturbance }\end{array}$ & T4-5 & $\begin{array}{l}\text { Enhanced } \\
\text { MRI }\end{array}$ & None & $\begin{array}{l}\text { Complete } \\
\text { excision }\end{array}$ & $\begin{array}{l}\text { HE, S-100, } \\
\text { CD34 }\end{array}$ & $\begin{array}{l}\text { Progressive gait } \\
\text { disturbance }\end{array}$ \\
\hline 8 & $\begin{array}{l}\text { Poriazova et al., } \\
2017 \text { (2) }\end{array}$ & $1 / \mathrm{M}$ & $\begin{array}{l}\text { Paresis in the } \\
\text { lower limbs, urinary } \\
\text { dysfunction }\end{array}$ & $\begin{array}{l}\text { Cauda } \\
\text { equina }\end{array}$ & MRI & None & $\begin{array}{l}\text { Complete } \\
\text { excision }\end{array}$ & $\mathrm{HE}$ & Recovery \\
\hline 9 & $\begin{array}{l}\text { Rosario et al., } \\
2017 \text { (3) }\end{array}$ & $40 / F$ & Back pain & $\mathrm{T} 10-11$ & $\begin{array}{l}\text { MRI, } \\
\text { myelogram }\end{array}$ & None & $\begin{array}{l}\text { Complete } \\
\text { excision }\end{array}$ & $\mathrm{HE}$ & Recovery \\
\hline 10 & Present case & $43 / \mathrm{M}$ & $\begin{array}{l}\text { Back pain and bilateral } \\
\text { shoulder pain }\end{array}$ & C7-T2 & $\begin{array}{l}\text { Enhanced } \\
\text { MRI }\end{array}$ & None & $\begin{array}{l}\text { Complete } \\
\text { excision }\end{array}$ & $\begin{array}{l}\text { HE, S-100, } \\
\text { CD34 }\end{array}$ & Limped \\
\hline
\end{tabular}

F, female; M, male; C, cervical; T, thoracic; CT, computed tomography; MRI, magnetic resonance imaging; NF, neurofibromatosis; HE, hematoxylin and eosin.

arranged in a striated, spiral, or lamellar arrangement. Immunohistochemical staining of the perineuroma was negative for the S-100 protein, which distinguished it from a neurofibroma. Ependymomas usually have a clear boundary, moderate cell density, and a single nucleolus that is round or oval in shape. Immunohistochemical staining of the GFAP protein in an ependymoma should be positive; however, in our case, staining of the GFAP protein was negative. This result does not support the presence of an ependymoma. This case is also the second reported case of intramedullary neurofibroma that underwent an immunohistochemical evaluation.

The means by which a neurofibroma came to exist in the spinal cord is difficult to explain. Furthermore, the detection of fat tissue at the posterior part of the lesion added to the complexity of this case study. In addition, the origin of the tumor requires further study. The most accepted hypothesis is that neurofibromas originate during embryonic neural tube development due to the ectopic neural crest cells $(17,18)$. All previously reported intramedullary neurofibromas were discovered in the posterior part of the spinal cord. Therefore, we believe that the intramedullary neurofibromas discussed in this case report may have originated from the Schwann cells in the spinal nerve roots. In the present case, the tumor was adjacent to the spinal nerve roots.

The most suitable treatment for intramedullary neurofibromas is surgery. Early diagnosis and aggressive surgery are the key factors to improve prognosis. Intramedullary neurofibromas are usually benign and often located in the posterior part of the spinal cord. Meticulous care should be exercised during removal of the tumor to prevent damage to the surrounding normal nerve tissue. In addition, transcranial electrical stimulation of motor-evoked 
potentials and multi-point recorded somatosensory evoked potentials should be used during spinal cord surgery to ensure complete tumor resection.

\section{Conclusions}

We reported a very rare case of spinal intramedullary neurofibroma. Despite its rarity, the diagnosis of intramedullary neurofibroma should be considered in patients with a solitary intramedullary tumor, especially when located in the dorsolateral spinal cord, and with dyskinesia supporting the corresponding spinal cord segment. However, the definitive diagnosis is based on a pathological examination. Complete surgical resection can improve the prognosis.

\section{Acknowledgments}

Funding: None.

\section{Footnote}

Conflicts of Interest: All authors have completed the ICMJE uniform disclosure form (available at https://qims. amegroups.com/article/view/10.21037/qims-21-940/coif). The authors have no conflicts of interest to declare.

Ethical Statement: The authors are accountable for all aspects of the work in ensuring that questions related to the accuracy or integrity of any part of the work are appropriately investigated and resolved. All procedures performed in this study were in accordance with the ethical standards of the institutional and/or national research committee(s) and with the Helsinki Declaration (as revised in 2013). Written informed consent was obtained from the patient for publication of this case report and accompanying images. A copy of the written consent form is available for review by the editorial office of this journal.

Open Access Statement: This is an Open Access article distributed in accordance with the Creative Commons Attribution-NonCommercial-NoDerivs 4.0 International License (CC BY-NC-ND 4.0), which permits the noncommercial replication and distribution of the article with the strict proviso that no changes or edits are made and the original work is properly cited (including links to both the formal publication through the relevant DOI and the license). See: https://creativecommons.org/licenses/by-nc-nd/4.0/.

\section{References}

1. Sanguinetti C, Specchia N, Gigante A, de Palma L, Greco F. Clinical and pathological aspects of solitary spinal neurofibroma. J Bone Joint Surg Br 1993;75:141-7.

2. Poriazova EG, Boykinova OB, Ivanov IS, Spasova MI, Bozhilov GB, Kevorkyan AK, Novakov SS. A technical problem in diagnosis clarity of solitary spinal cord neurofibroma in an eleven-month-old boy. Folia Med (Plovdiv) 2017;59:357-61.

3. Rosario MS, Murakami H, Kato S, Fujii M, Yonezawa $\mathrm{N}$, Tsuchiya H. Solitary thoracic intramedullary spinal neurofibroma microsurgically extirpated via recapping T-saw laminoplasty. J Orthop Surg (Hong Kong) 2017;25:2309499017691003.

4. Tonnis W, Friedmann G, Nittner K. Roentgenological diagnosis and differential diagnosis of intraspinal tumors with a reference to clinical symptomatology. Fortschr Geb Rontgenstr Nuklearmed 1958;88:288-301.

5. Nittner K. Spinal meningiomas, neurinomas and neurofibromas, and hourglass tumours. In: Vinken PH, Bruyn GW. editors. Handbook of Clinical Neurology. New York: American Elsevier Publishing, 1976:20;177-322.

6. Gelabert M, Prieto A, Sobrińo A, García-Pravos A, Bandin F, Bollar A, Calle J, García-Allut A. Cervical intramedullary neurofibroma. Rev Neurol 1996;24:836-7.

7. Oka H, Tachibana S, Yada K, Suwa T, Iida H, Mii K. Intramedullary neurofibroma in the cervical spinal cord; a case report. No Shinkei Geka 1992;20:599-603.

8. Sharma $V$, Newton G. Cervical intramedullary neurofibroma. J Korean Med Sci 1990;5:165-7.

9. Gelabert González M, Garcia Allut A, Conde Alonso C, Bollar Zabala A, Martinez Rumbo R, Reyes Oliveros F. Intramedullary spinal neurofibroma diagnosed with computed tomography: report of a case. Neurosurgery 1985;16:543-5.

10. Sharma R, Tandon SC, Mohanty S, Gupta S. Intramedullary neurofibroma of the cervical spinal cord: case report with review of the literature. Neurosurgery 1984;15:546-8.

11. Young HA, Robb P, Hardy DG. Large intramedullary neurofibroma of the conus medullaris: case report. Neurosurgery 1983;13:48-51.

12. Arishima H, Kitai R, Kodera T, Yamada S, Kikuta K. A large intramedullary neurofibroma in the thoracic spinal cord: case report. Neurol Med Chir (Tokyo) 2014;54:752-6.

13. Hirose T, Sano T, Hizawa K. Ultrastructural localization 
of S-100 protein in neurofibroma. Acta Neuropathol 1986;69:103-10.

14. Ushigome S, Takakuwa T, Hyuga M, Tadokoro M, Shinagawa T. Perineurial cell tumor and the significance of the perineurial cells in neurofibroma. Acta Pathol Jpn 1986;36:973-87.

15. Naber U, Friedrich RE, Glatzel M, Mautner VF, Hagel C. Podoplanin and CD34 in peripheral nerve sheath tumours: focus on neurofibromatosis 1-associated atypical neurofibroma. J Neurooncol 2011;103:239-45.

16. Hirose T, Tani T, Shimada T, Ishizawa K, Shimada S, Sano

Cite this article as: Zhao Z, Li J, Chen Y, Liu J, Cai Q, Li Y, Zou J, Zhou J, Li Y, Liang Y, Yang H. A solitary intramedullary neurofibroma in the cervicothoracic spinal cord: a case study and literature analysis. Quant Imaging Med Surg 2022;12(5):3007-3013. doi: 10.21037/qims-21-940
T. Immunohistochemical demonstration of EMA/Glut1positive perineurial cells and CD34-positive fibroblastic cells in peripheral nerve sheath tumors. Mod Pathol 2003;16:293-8.

17. Vailati G, Occhiogrosso M, Troccoli V. Intramedullary thoracic schwannoma. Surg Neurol 1979;11:60-2.

18. Conti P, Pansini G, Mouchaty H, Capuano C, Conti R. Spinal neurinomas: retrospective analysis and long-term outcome of 179 consecutively operated cases and review of the literature. Surg Neurol 2004;61:34-43; discussion 44. 